\title{
Growth, Yield, Efficiency, and Fruit Quality of Five Navel Orange Clones During 4 Years $^{1}$
}

\author{
Agripino Pérez-López and Carlos J. Torres ${ }^{2}$
}

\section{ABSTRACT}

\begin{abstract}
Clone 7 can increase three-fold the production of navel oranges in Puerto Rico. Clone 7 produced 293 fruits per tree. The number and weight of fruits per tree increased with age, whereas the size and fruit weight, navel volume and peel weight diminished.

Growth measurements such as rootstock and scion diameter, scion/rootstock ratio, canopy diameter, tree height, and canopy volume are not as good parameters for the selection of navel orange clones as the number of fruits per $\mathrm{m}^{3}$ of canopy volume. Screening for varieties according to yield revealed that clones 5 and 7 were the most productive and that they should be recommended to the citrus growers.

Clones 5 and 7 also had the highest Brix and acidity values, and an intermediate $\mathrm{pH}$, which contribute to an appropriate Brix/acid ratio, typical of the high quality of these navel clones. The smallest fruits had significantly the highest juice percentage.
\end{abstract}

\section{INTRODUCTION}

Citrus fruits are among the most important fruits of Puerto Rico. However, production has gone into a steady state since 15 years ago when the number of oranges produced has remained at about 178 million fruits per year while fruit value has increased tremendously. During the last 15 years the price per fruit increased from 0.68 to 1.75 cents (6). The value of imported oranges from the United States (as processed and fresh fruit) was $\$ 13.1$ million (4) and the farm value of oranges produced in the Island reached $\$ 3.08$ million.

Low production could be attributed, among other things, to the lack of new improved varieties.

Espinet-Colon (1) suggests that the citrus growers are willing to improve their orchards with better varieties. Troche Ducot and González Villafañe (5) demonstrated that the mean number of oranges per tree was 96.

Results from our experiments show that we can increase three-fold the island fruit production per tree with the new clones recommended in this report.

${ }^{1}$ Manuscript submitted to Editorial Board October 3, 1983.

${ }^{2}$ Horticulturist-Professor, Isabela Agricultural Research and Development Center and Assistant Horticulturist in Charge, Adjuntas Substation, Agricultural Experiment Station, College of Agricultural Sciences, Mayagüez Campus, respectively, University of Puerto Rico, Río Piedras, P.R. 


\section{MATERIALS AND METHODS}

Five navel orange clones selected in the region where navel oranges are mostly grown, (Adjuntas, Utuado, Lares, San Sebastián, and Maricao) were bud-grafted on native orange rootstock. The clones included in this experiment were numbered $4,5,6,7$ and 8 .

Native orange seedlings, pregerminated in sandbeds were transplanted into black polyethylene bags filled with a $1: 1$ soil to filter-press cake mixture. Two weeks before planting the seedlings, the bags were treated with methyl bromide at a rate of $1.8 \mathrm{~kg}$ per $2.8 \mathrm{~m}^{3}$ of soil mixture.

Trees were grown in an Alonso clay. This is a light, friable, fertile, steep soil typical of the central mountain region of Puerto Rico.

Seedlings were grafted with the five above-mentioned navel clones, and 6 months later they were transplanted to the field. The clones were laid out in the field in a randomized block design October 4, 1966 spaced at $6 \mathrm{~m} \times 6 \mathrm{~m}$. Weeding, fertilizing and other management practices were performed in accordance with the reccommendations of the Agricultural Experiment Station (2).

Tree growth was measured during the summer 1981. Rootstock and scion diameter were measured to the nearest $0.1 \mathrm{~cm}$. Tree height was measured to the nearest $0.1 \mathrm{ft}$. Canopy diameter was measured to the nearest $0.1 \mathrm{~m}$ crossing from east to west.

Canopy volume was determined by the formula:

$$
\text { C.V. }=\frac{\text { canopy diameter }{ }^{2} \times \text { tree height }^{-}}{4}
$$

The efficiency was calculated by dividing the number of fruits harvested per tree by the number of cubic meters of canopy.

Two healthy trees per clone, replicated 5 times, were included in the study. Ten-fruit samples were chosen at random around the canopy of each tree. Undersized or injured fruits were discarded. Weight of all samples was recorded. Five fruits were analyzed for $\mathrm{pH}$, total soluble solids (TSS) and acidity by titration with $\mathrm{NaOH}$.

Peel weight per fruit was determined after the extraction of the juice with a hand-operated juice extractor. Navel size was determined by cutting the fruit along the axis line, splitting the navel and measuring the height and diameter of the navel. The volume of the navel was then calculated by substitution with these measurements in the formula:

$$
\text { Volume }=\frac{\text { diameter }^{2} \times \text { height }}{4}
$$

\section{RESULTS AND DISCUSSION}

Table 1 shows growth measurements.

There is not much difference among clones for rootstock and scion 
diameter and tree height. However, clones 6 and 8 tended to be shorter and thinner. This result could account for the low yielding capacity of these two clones (table 2).

No significant difference among clones was found for canopy volume and scion rootstock ratio. These results suggest that the native orange could be used safely as a rootstock for grafting navel oranges.

There was a significant variation among clones in canopy diameter and tree height. However, these growth attributes were not associated with fruit production.

\section{EFFICIENCY}

Table 1 indicates that clones 5 and 7 are equally efficient and better than clones 4, 6 and 8, which were equally inefficient. This fact suggests that efficiency could be used as a measure for screening navel orange varieties.

TABLE 1.-Growth measurements and efficiency (number of fruits per cubic meter of canopy) of the five navel orange clones

\begin{tabular}{cccccccc}
\hline $\begin{array}{c}\text { Clone } \\
\text { No. }\end{array}$ & $\begin{array}{c}\text { Rootstock } \\
\text { diameter }\end{array}$ & $\begin{array}{c}\text { Scion } \\
\text { diameter }\end{array}$ & $\begin{array}{c}\text { Scion/ } \\
\text { rootstock }\end{array}$ & $\begin{array}{c}\text { Canopy } \\
\text { diameter }\end{array}$ & $\begin{array}{c}\text { Tree } \\
\text { height }\end{array}$ & $\begin{array}{c}\text { Canopy } \\
\text { volume }\end{array}$ & Efficiency \\
\hline & $c m$ & $c m$ & & $m$ & $m$ & $m^{3}$ & $\left(\right.$ fruits $\left./ m^{3}\right)$ \\
4 & $19.0 \mathrm{a}^{1}$ & $17.3 \mathrm{a}$ & $0.91 \mathrm{a}$ & $4.4 \mathrm{a}$ & $3.6 \mathrm{a}$ & $17.4 \mathrm{a}$ & $12.5 \mathrm{~b}$ \\
5 & $17.7 \mathrm{ab}$ & $16.5 \mathrm{ab}$ & $0.95 \mathrm{a}$ & $3.9 \mathrm{ab}$ & $3.4 \mathrm{ab}$ & $13.3 \mathrm{a}$ & $18.0 \mathrm{a}$ \\
6 & $16.7 \mathrm{ab}$ & $14.8 \mathrm{~b}$ & $0.94 \mathrm{a}$ & $3.8 \mathrm{bc}$ & $3.5 \mathrm{ab}$ & $14.1 \mathrm{a}$ & $13.8 \mathrm{~b}$ \\
7 & $18.3 \mathrm{ab}$ & $16.5 \mathrm{ab}$ & $0.90 \mathrm{a}$ & $4.1 \mathrm{a}$ & $3.5 \mathrm{ab}$ & $14.9 \mathrm{a}$ & $19.7 \mathrm{a}$ \\
8 & $15.9 \mathrm{~b}$ & $15.2 \mathrm{~b}$ & $0.95 \mathrm{a}$ & $3.6 \mathrm{c}$ & $3.2 \mathrm{~b}$ & $16.2 \mathrm{a}$ & $12.0 \mathrm{~b}$ \\
\hline
\end{tabular}

${ }^{1}$ Means followed by one or more letters in common do not differ significantly at the $5 \%$ level by Duncan's multiple range test.

Table 2 shows data on yield and quality measurements. The number and weight of fruits per tree increased significantly from 149 to 302 , and from 48 to 104, respectively, as the trees became older. Clones 5 and 7 produced a significantly higher number of fruits than clones 4, 6 and 8 . Clones 4, 5 and 7 produced heavier fruits than clones 6 and 8 .

These results suggest that clones 5 and 7 could be selected as new promising navel orange varieties. The heavy crop of clone 4 was due to its big navel and since the navel is not a good fruit attribute, this clone is not recommended for commerical plantings.

\section{NAVEL SIZE AND WEIGHT OF FRUIT AND PEEL}

Clone 4 produced the biggest navel $\left(33 \mathrm{~cm}^{3}\right)$ and the heaviest fruit and peel. Clones 6 and 8 produced the smallest navel and the lightest fruits. As the tree aged fruit weight and navel size decreased. The big differences between year 1978 and the other 3 years of this study could be due to the 
TABLE 2.-Production and quality of fruits of five navel orange clones evaluated during years 1978, 1979, 1980 and 1981

\begin{tabular}{|c|c|c|c|c|c|c|c|c|c|c|c|}
\hline $\begin{array}{l}\text { Clone } \\
\text { number } \\
\text { and year }\end{array}$ & $\begin{array}{l}\text { Fruits } \\
\text { per tree }\end{array}$ & $\begin{array}{l}\text { Weight of } \\
\text { fruits per } \\
\text { tree }\end{array}$ & $\begin{array}{l}\text { Navel } \\
\text { size }\end{array}$ & $\begin{array}{l}\text { Weight } \\
\text { per fruit }\end{array}$ & $\begin{array}{c}\text { Peel } \\
\text { weight } \\
\text { per fruit }\end{array}$ & $\begin{array}{l}\text { Juice } \\
\text { content }\end{array}$ & Shape & $\begin{array}{l}\text { Brix/acid } \\
\text { ratio }\end{array}$ & Brix & Acidity & $\mathrm{pH}$ \\
\hline Clone & no. & $\mathrm{kg}$ & $\mathrm{cm}^{3}$ & $g$ & $g$ & $\%$ & $D: / H$ ratio & & $\%$ & $\%$ & \\
\hline 4 & $217 b^{1}$ & $88 \mathrm{ab}$ & $33 a$ & $405 a$ & $205 a$ & $49 b$ & $0.97 \mathrm{~b}$ & $14.8 \mathrm{a}$ & $11.3 \mathrm{~b}$ & $0.75 b$ & $3.69 a$ \\
\hline 5 & $239 a b$ & $86 a b$ & $25 \mathrm{~b}$ & $356 \mathrm{~b}$ & $176 \mathrm{~b}$ & $50 \mathrm{ab}$ & $0.97 \mathrm{~b}$ & $14.8 \mathrm{a}$ & $11.7 \mathrm{a}$ & $0.79 a$ & $3.64 \mathrm{~b}$ \\
\hline 6 & $194 b$ & $62 c$ & $17 \mathrm{bc}$ & $322 \mathrm{bc}$ & $159 c$ & $52 \mathrm{a}$ & $0.97 \mathrm{~b}$ & $15.1 \mathrm{a}$ & $10.9 \mathrm{~b}$ & $0.73 \mathrm{c}$ & $3.64 \mathrm{~b}$ \\
\hline 7 & $293 a$ & $102 a$ & $23 \mathrm{~b}$ & $352 \mathrm{~b}$ & $171 b$ & $50 \mathrm{ab}$ & $0.96 \mathrm{~b}$ & $14.5 \mathrm{a}$ & $11.6 \mathrm{a}$ & $0.80 \mathrm{a}$ & $3.63 \mathrm{~b}$ \\
\hline 8 & $195 b$ & $61 c$ & $16 \mathrm{c}$ & $314 c$ & $156 \mathrm{c}$ & $52 \mathrm{a}$ & $0.99 a$ & $14.4 \mathrm{a}$ & $10.9 \mathrm{~b}$ & $0.76 \mathrm{~b}$ & $3.60 \mathrm{c}$ \\
\hline \multicolumn{12}{|l|}{ Year } \\
\hline 1978 & $149 d$ & $48 c$ & $24 \mathrm{~b}$ & $324 c$ & $153 c$ & $54 a$ & $0.96 c$ & $14.8 \mathrm{~b}$ & $11.5 \mathrm{~b}$ & $0.77 \mathrm{~b}$ & $3.70 \mathrm{~b}$ \\
\hline 1979 & $214 \mathrm{c}$ & $82 b$ & $29 a$ & $382 a$ & $187 a$ & $49 c$ & $0.98 \mathrm{~b}$ & $16.6 \mathrm{a}$ & $10.9 \mathrm{c}$ & $0.66 \mathrm{c}$ & $3.80 \mathrm{a}$ \\
\hline 1980 & $245 b$ & $86 \mathrm{~b}$ & $24 \mathrm{~b}$ & $351 \mathrm{~b}$ & $179 \mathrm{ab}$ & $51 b$ & $0.97 \mathrm{~b}$ & $13.6 \mathrm{c}$ & $11.8 \mathrm{a}$ & $0.87 \mathrm{a}$ & $3.56 \mathrm{c}$ \\
\hline 1981 & $302 a$ & $104 a$ & $14 \mathrm{c}$ & $343 b$ & $175 \mathrm{~b}$ & $49 c$ & $0.99 a$ & $14.3 \mathrm{c}$ & $10.8 c$ & $0.76 \mathrm{~b}$ & $3.49 \mathrm{~d}$ \\
\hline
\end{tabular}

${ }^{1}$ Means followed by one or more letters in common do not differ significantly at the $5 \%$ level by Duncan's multiple range test. 


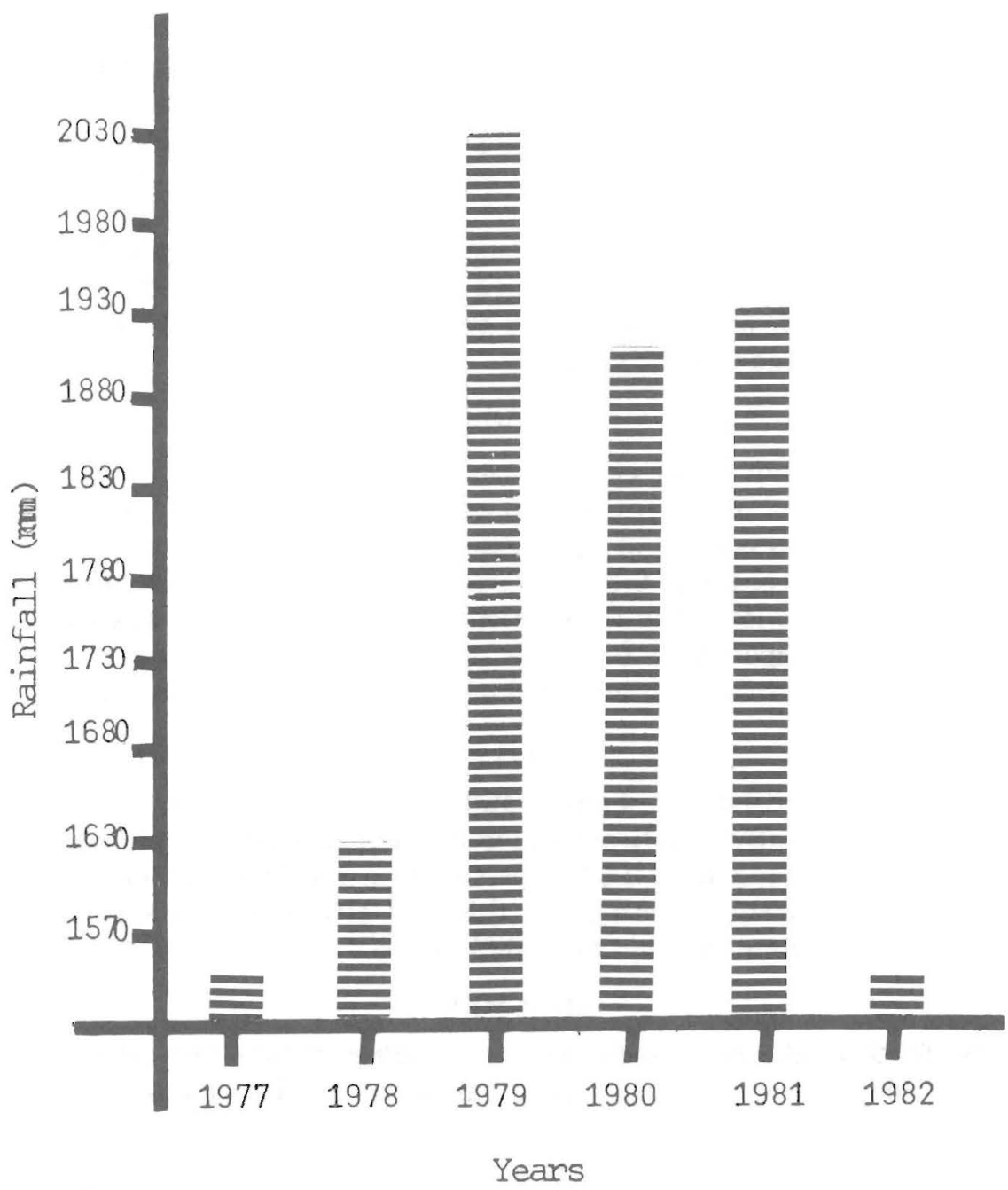

Fig. 1.-Rainfall at the Adjuntas Agricultural Experiment Substation during the years 1977 through 1982.

very low rainfall in 1978 , which was $1,630 \mathrm{~mm}$ as compared to $2,030 \mathrm{~mm}$, 1900 and $1930 \mathrm{~mm}$ in 1979, 1980 and 1981, respectively (fig. 1).

A big navel in this orange appears to be a drawback for juice content, since clones with the biggest navels had significantly the lowest juice percent.

\section{JUICE CONTENT AND FRUIT SHAPE}

There was no significant difference for juice content among clones 5 , 6,7 and 8 . Clone 4 had $49 \%$ juice content per fruit, which was significantly 
lower than that of clones 6 and 8 . Clones 6 and 8 had the smallest navels.

The juice content per fruit during 1978 was $54 \%$ significantly higher than in 1979, 1980 and 1981. This probably was due to the fact that the fruits were very small because of drought (fig. 1). During 1979 and 1981 the juice content per fruit was $49 \%$, which was significantly lower than that of 1980 which was $51 \%$.

The fruits in most of the clones included in this study had an axis longer than the diameter. Clone 8 had a 0.99 diameter:height $(\mathrm{D}: \mathrm{H})$ ratio, which was significantly higher than that of the other clones: 0.97 for clones 4 and 5 , and 0.96 for clone 7 .

\section{ACIDITY}

The acid content of the clones varied from $0.73 \%$ to $0.80 \%$, which is all right for navel oranges. Clones 5 and 7 , which were selected as the best yielders, had equal and significantly higher acid content than the other three clones. Clone 6 had a significantly lower acid content than the other four clones (table 2). In 1979 and 1980 acid content was lowest and highest, respectively (table 2). This difference was significant, whereas the difference between 1978 and 1981 was nonsignificant.

\section{$\mathrm{PH}$}

Clones 4 and 8 had the highest and the lowest pH levels (table 2). There was a greatly significant difference among years for $\mathrm{pH}$ values, which varied from 3.49 to 3.80 . This variation was bigger among years than among clones, suggesting that this fruit attribute is more affected by yearly variations than by clonal differences.

\section{RESUMEN}

Se llevó a cabo un experimento en la región montañosa central de Puerto Rico para evaluar cinco clones de china nevo (naranja navel) para obtener variedades mejoradas de este frutal.

Los resultados demuestran que la producción media de 96 frutas por árbol informada previamente puede triplicarse si se usan los clones 5 y 7 , los cuales produjeron 239 y 293 frutas por árbol, respectivamente.

Otros resultados de este estudio demostraron que el número y peso global de las frutas por árbol en el huerto experimental aumenta con la longevidad de los árboles y que el peso medio de la fruta y el tamaño del ombligo se reduce.

Mediciones del crecimiento, tales como diámetros del patrón y el injerto, la relación entre injerto y patrón, el diámetro y volumen de la copa y la altura del árbol no son tan eficaces como la determinación de la eficiencia productiva calculada como número de frutas por metro cúbico de la copa que sirva de base para seleccionar buenos clones de chinas nevo. 
Por el método clásico de seleccionar clones a base de una buena producción de frutas por árbol, podemos concluir que los clones 5 y 7 fueron los más productivos y que deben recomendarse a los citricultores.

El clon 4 fue el que produjo las frutas más grandes (405 g) y una producción por árbol que compara con los dos clones que estamos recomendando, pero como éste tuvo mucha más cáscara y un ombligo significativamente más grande, no lo recomendamos como una variedad comercial.

Los clones 5 y 7 que estamos recomendando para propagarse tuvieron los valores de acidez y Brix más altos y un pH intermedio, por lo cual tienen una buena relación de Brix:ácido que les da una buena calidad para consumo en fresco o en conserva.

Las frutas pequeñas tuvieron significativamente mayor porcentaje de jugo que las grandes, lo cual sugiere que se tome esto en cuenta cuando se clasifiquen, de suerte que las grandes se destinen al mercado en fresco y las pequeñas para conservas o jugo.

\section{LITERATURE CITED}

1. Espinet-Colón, G. R., 1968. Producción y estructura del mercado de cítricas en Puerto Rico, Esta. Exp. Agríc. Univ. P.R. Bol. 215.

2. Estación Experimental Agricola de Puerto Rico, 1977. Conjunto tecnológico para la producción de cítricas, Publ. 113.

3. Departamento de Agricultura, Estado Libre Asociado de Puerto Rico, 1979. Ingreso Agricola de Puerto Rico, 1977-78, 1978-79.

4. Departamento de Agricultura, Estado Libre Asociado de Puerto Rico, 1981. Bol. Sem. Estad. Agric. Julio-Dic. 1981. Santurce, Puerto Rico.

5. Troche-Ducot, J. L. y González-Villafañe, E., 1982. Costos e ingresos en la producción comercial de chinas Valencia y Nebo en Puerto Rico, Esta. Exp. Agríc. Univ. P.R., Publ. 145.

6. Zapata-Acosta, J., 1980. Mimeógrafo sobre frutas, Esta. Exp. Agric., Univ. P.R. 